\title{
Front Matter: Volume 11289
}

, "Front Matter: Volume 11289," Proc. SPIE 11289, Photonic and Phononic Properties of Engineered Nanostructures X, 112892G (7 April 2020); doi: $10.1117 / 12.2570289$

SPIE. Event: SPIE OPTO, 2020, San Francisco, California, United States 


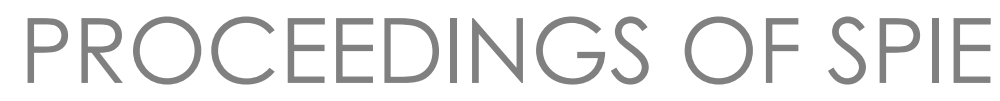

\title{
Photonic and Phononic Properties of Engineered Nanostructures $X$
}

\author{
Ali Adibi \\ Shawn-Yu Lin \\ Axel Scherer \\ Editors
}

3-6 February 2020

San Francisco, California, United States

Sponsored and Published by

SPIE 
The papers in this volume were part of the technical conference cited on the cover and title page. Papers were selected and subject to review by the editors and conference program committee. Some conference presentations may not be available for publication. Additional papers and presentation recordings may be available online in the SPIE Digital Library at SPIEDigitalLibrary.org.

The papers reflect the work and thoughts of the authors and are published herein as submitted. The publisher is not responsible for the validity of the information or for any outcomes resulting from reliance thereon.

Please use the following format to cite material from these proceedings:

Author(s), "Title of Paper," in Photonic and Phononic Properties of Engineered Nanostructures $X$, edited by Ali Adibi, Shawn-Yu Lin, Axel Scherer, Proceedings of SPIE Vol. 11289 (SPIE, Bellingham, WA, 2020) Seven-digit Article CID Number.

ISSN: 0277-786X

ISSN: 1996-756X (electronic)

ISBN: 9781510633414

ISBN: 9781510633421 (electronic)

Published by

SPIE

P.O. Box 10, Bellingham, Washington 98227-0010 USA

Telephone +1 3606763290 (Pacific Time) · Fax +1 3606471445

SPIE.org

Copyright (C) 2020, Society of Photo-Optical Instrumentation Engineers.

Copying of material in this book for internal or personal use, or for the internal or personal use of specific clients, beyond the fair use provisions granted by the U.S. Copyright Law is authorized by SPIE subject to payment of copying fees. The Transactional Reporting Service base fee for this volume is $\$ 18.00$ per article (or portion thereof), which should be paid directly to the Copyright Clearance Center (CCC), 222 Rosewood Drive, Danvers, MA 01923. Payment may also be made electronically through CCC Online at copyright.com. Other copying for republication, resale, advertising or promotion, or any form of systematic or multiple reproduction of any material in this book is prohibited except with permission in writing from the publisher. The CCC fee code is 0277$786 \mathrm{X} / 20 / \$ 18.00$.

Printed in the United States of America.

Publication of record for individual papers is online in the SPIE Digital Library.

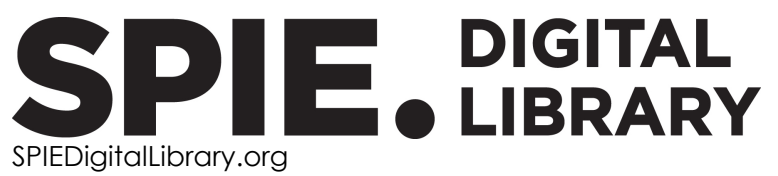

Paper Numbering: Proceedings of SPIE follow an e-First publication model. A unique citation identifier (CID) number is assigned to each article at the time of publication. Utilization of CIDs allows articles to be fully citable as soon as they are published online, and connects the same identifier to all online and print versions of the publication. SPIE uses a seven-digit CID article numbering system structured as follows:

- The first five digits correspond to the SPIE volume number.

- The last two digits indicate publication order within the volume using a Base 36 numbering system employing both numerals and letters. These two-number sets start with $00,01,02,03,04$, 05, 06, 07, 08, 09, 0A, OB ... 0Z, followed by 10-1Z, 20-2Z, etc. The CID Number appears on each page of the manuscript. 


\title{
Contents
}

\author{
vii Authors \\ ix Conference Committee
}

PHOTONIC METAMATERIALS

1128905 Strong self-induced nonreciprocal transmission by using nonlinear PT-symmetric epsilon-near-zero metamaterials [1 1289-5]

PHOTONIC CRYSTALS

$1128909 \quad$ Higher-order photonic topological insulator metasurfaces [1 1289-9]

$11289 \mathrm{OB} \quad$ Quantifying the saturation of structural color from thin film polymeric photonic crystals [11289-11]

PLASMONIC NANOSTRUCTURES

$11289 \mathrm{OU} \quad$ Hybrid plasmonic-dielectric resonant waveguide grating for wavelength-selective diffraction [11289-30]

$11289 \mathrm{OV}$ Polarization conversion of surface plasmons through multi-vector superimposed gratings [11289-31]

RESONANCE-BASED PHOTONIC DEVICES AND APPLICATIONS

1128911 Cylindrical hyperbolic metamaterials exhibiting superscattering with whispering gallery-like resonance [11289-37]

QUANTUM NANOSTRUCTURES

1128914 Wavelength-resolved Purcell enhancement of PbS/CdS quantum dots measured on a chip-based plafform [11289-40]

1128915 Integrated quantum dot optomechanics [11289-41] 
PHASE-CHANGE MATERIALS FOR OPTOELECTRONICS

$112891 \mathrm{E} \quad$ Sub-wavelength plasmonic-enhanced phase-change memory [11289-50]

PHOTONIC NANOSTRUCTURES FOR SENSING AND IMAGING

$1128911 \quad$ Self-referenced integrated plasmonic device based on engineered periodic nanostructures for sensing application [1 1289-54]

$112891 \mathrm{~K} \quad$ Analysis of biological creature color appearance via FDTD simulation [11289-56]

NOVEL MATERIALS AND PHENOMENA IN ENGINEERED NANOSTRUCTURES I

$112891 \mathrm{~L} \quad$ Filling in the missing link: monolithic optical isolators on silicon with high performance, broadband operation, and polarization diversity (Invited Paper) [1 1289-57]

$112891 \mathrm{~N} \quad$ Visible frequency active hyperbolic metamaterials [11289-59]

$1128910 \quad$ High-performance infrared thermoelectric bolometers based on nanomembranes [11289-60]

NOVEL MATERIALS AND PHENOMENA IN ENGINEERED NANOSTRUCTURES II

$112891 Q \quad$ Optical scattering measurements of random anti-reflective nanostructured surfaces in the mid- and long-wave IR [11289-62]

$112891 \mathrm{R} \quad$ Resonant and scattering properties of tungsten disulfide WS $\mathbf{W}_{2}$ nanoantennas [11289-63]

MODELING AND SIMULATION OF NANOPHOTONIC STRUCTURES

11289 1T A few novel phenomena in electromagnetic scattering (Invited Paper) [11289-65]

$112891 \mathrm{~N} \quad$ Numerical modeling of opto-electric characterization of GaAs/In $0.2 \mathrm{Ga}_{0.8} \mathrm{As}$ nanowire solar cells [11289-69]

POSTER SESSION

$1128912 \quad$ Tailoring response of a cluster of nanoparticles on a substrate and its application for design of geometrical phase elements [1 1289-71]

iv 
1128921 Analyzing the light transmittance through a virtual chicken cornea tissue model via simulation [11289-73]

1128923 Ultra-coherent supercontinuum generation in isopropanol-silica based photonic crystal fiber at $1300 \mathrm{~nm}$ and $1600 \mathrm{~nm}$ wavelengths [11289-76]

$1128927 \quad$ Handedness-dependent electromagnetic induced transparency in dielectric polymer-based 3D structures [11289-80]

1128929 Biaxial hyperbolic metamaterials [11289-82]

11289 2C Dynamically tunable reflecting NIR band-pass filter based on hybrid graphene-nanometallic structure [11289-85] 
Proc. of SPIE Vol. 11289 112892G-6

Downloaded From: https://www.spiedigitallibrary.org/conference-proceedings-of-spie on 26 Apr 2023 Terms of Use: https://www.spiedigitallibrary.org/terms-of-use 


\section{Authors}

Numbers in the index correspond to the last two digits of the seven-digit citation identifier (CID) article numbering system used in Proceedings of SPIE. The first five digits reflect the volume number. Base 36 numbering is employed for the last two digits and indicates the order of articles within the volume. Numbers start with 00, 01, 02, 03, 04, 05, 06, 07, 08, 09, OA, OB...0Z, followed by 10-1Z, 20-2Z, etc.

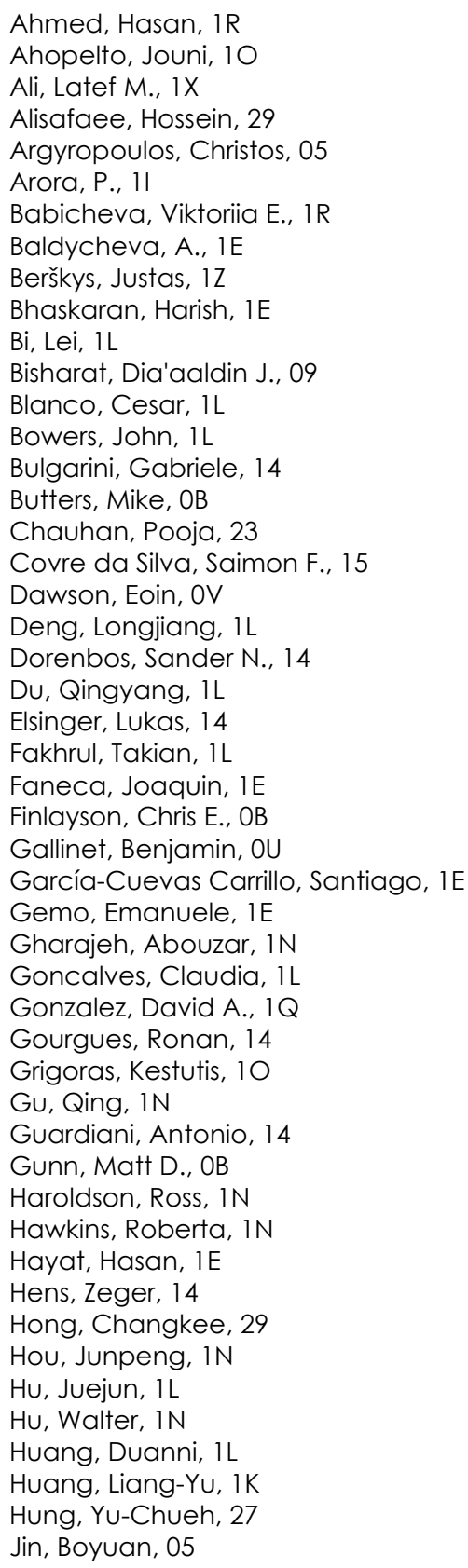

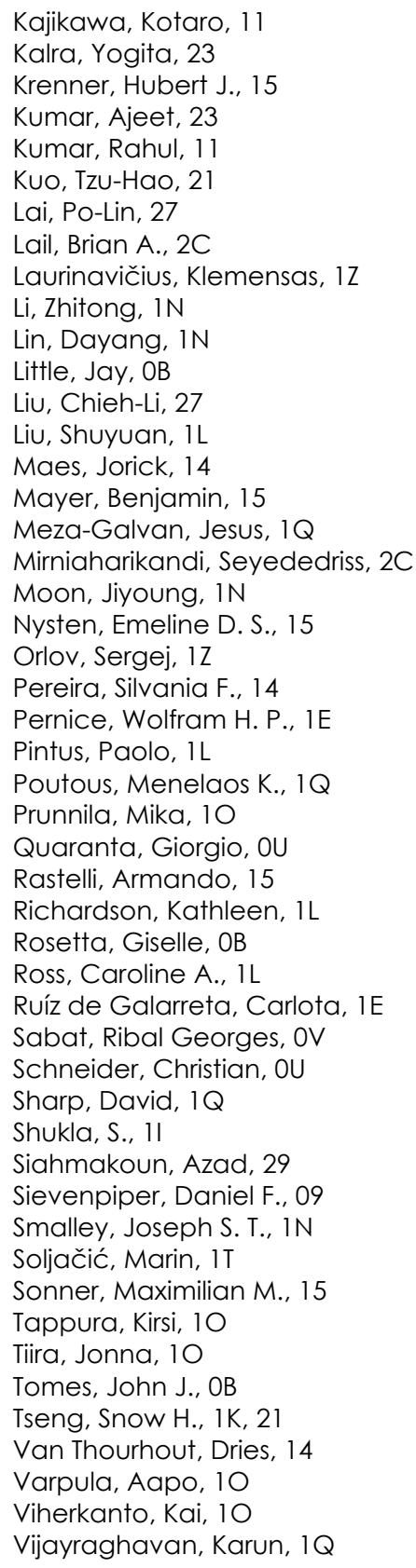


Vogele, Anja, 15

Wang, Chuangtang, $1 \mathrm{~L}$

Weiß, Matthias, 15

Wright, C. David, 1E

Yang, Yi, $1 T$

Youngblood, Nathan, IE

Yuan, Xueyong, 15

Zadeh, Iman E., 14

Zakhidov, Anvar, $1 \mathrm{~N}$

Zhang, Chuanwei, 1N

Zhang, Yan, 1L

Zhang, Yifei, $1 \mathrm{~L}$

Zwiller, Val, 14 


\section{Conference Committee}

Symposium Chairs

Sailing He, KTH Royal Institute of Technology (Sweden) and Zhejiang University (China)

Yasuhiro Koike, Keio University (Japan)

Symposium Co-chairs

Connie J. Chang-Hasnain, University of California, Berkeley (United States)

Graham T. Reed, Optoelectronics Research Centre, University of Southampton (United Kingdom)

Program Track Chair

Ali Adibi, Georgia Institute of Technology (United States)

Conference Chairs

Ali Adibi, Georgia Institute of Technology (United States)

Shawn-Yu Lin, Rensselaer Polytechnic Institute (United States)

Axel Scherer, Caltech (United States)

Conference Program Committee

Andrea Alù, The City University of New York Advanced Science Research Center (United States)

Amir Arbabi, University of Massachusetts Amherst (United States)

Ali A. Eftekhar, Georgia Institute of Technology (United States)

Mercedeh Khajavikhan, CREOL, The College of Optics and Photonics, University of Central Florida (United States)

Reginald K. Lee, Caltech (United States)

Marko Loncar, Harvard John A. Paulson School of Engineering and Applied Sciences (United States)

Arka Majumdar, University of Washington (United States)

Susumu Noda, Kyoto University Graduate School of Engineering (Japan)

Masaya Notomi, NTT Basic Research Laboratories (Japan)

Ekmel Özbay, Bilkent University (Turkey)

Yong Xu, Virginia Polytechnic Institute and State University (United States)

Eli Yablonovitch, University of California, Berkeley (United States)

Rashid Zia, Brown University (United States) 
Session Chairs

1 Recent Advances in Engineered Nanostructures

Ali Adibi, Georgia Institute of Technology (United States)

2 Photonic Metamaterials

Shawn-Yu Lin, Rensselaer Polytechnic Institute (United States)

3 Photonic Crystals

Yeshaiahu Fainman, University of California, San Diego (United States)

4 Photonic Metasurfaces I

Ekmel Özbay, Bilkent University (Turkey)

5 Photonic Metasurfaces II

Ali Adibi, Georgia Institute of Technology (United States)

6 Novel Design Techniques for Photonic Nanostructures

Jennifer A. Dionne, Stanford University (United States)

$7 \quad$ Plasmonic Nanostructures

Amir Arbabi, University of Massachusetts Amherst (United States)

8 Resonance-Based Photonic Devices and Applications

Amir Safavi-Naeini, Stanford University (United States)

9 Quantum Nanostructures

Kartik Srinivasan, National Institute of Standards and Technology (United States)

10 Phononic Crystals and Optomechanical Structures

Harish Bhaskaran, University of Oxford (United Kingdom)

11 Phase-Change Materials for Optoelectronics

Martin Wegener, Karlsruher Institut für Technologie (Germany)

12 Photonic Nanostructures for Sensing and Imaging

Juejun Hu, Massachusetts Institute of Technology (United States)

13 Novel Materials and Phenomena in Engineered Nanostructures I Luca Dal Negro, Boston University (United States)

14 Novel Materials and Phenomena in Engineered Nanostructures II Yi Yang, Massachusetts Institute of Technology (United States)

15 Modeling and Simulation of Nanophotonic Structures

Shoufeng Lan, Georgia Institute of Technology (United States) 